\title{
Yield Components and Diversity of Qualitative Characters of Fifty Accessions of Inbred Maize Lines
}

\author{
Lina Herlina ${ }^{*}$ \\ ICABIOGRAD, IAARD, Jl. Tentara Pelajar No. 3A Cimanggu - Bogor 16111, West Java, Indonesia
}

\begin{abstract}
Challenges in maize production in Indonesia have led to the importance of assembling high yield varieties of maize. To create superior maize varieties requires genetic material particularly inbred lines as the basic material for setting population to perform crossing and selection. The research aims to characterize the quantitative and qualitative characters of 50 inbred maize which contributed to high yield and also to determine the uniformity of the tested inbred lines. A randomized group design with 3 replications was performed. Based on the results, characters with the highest variance were the number of seeds per ear and 1000 bulk weight. There were five characters with high heritability, including ear diameter, number of seeds per ear, ear wet weight, ear dry weight, and dry seed weight. The highest heritability was obtained from dry seed weight, while the lowest heritability was the number of lines per ear. The accession with the highest dry seed weight was P4G19(S)C2-114-3-1-2 (70 g), accession with the largest ear diameter and the highest number of seeds per ear was P4G19(S)C2-15-1 -1-4, and the one with the largest ear dry weight was P4G18(S)C2-18-1-1. The results of the analysis on qualitative characters showed that the variation was still high within the tested lines.
\end{abstract}

\section{Introduction}

When conditions of climate change are increasingly uncertain and the global economic crisis has worsened for more than a year due to the Covid-19 pandemic [1], Indonesia must be aware of the domestic food problem. Corn is the second main food commodity after rice in Indonesia [2], however maize is the main food supplier for dry land agricultural cultivation, because the majority of maize is cultivated on dry land [3]. This is consistent with the environment from which the world's maize plants originated, namely in Central America (Southern Mexico).

Over thousands of years the maize plant has adapted as a plant that has inherently drought resistance [4]. Therefore, the fact that climate change which tends to global warming would have implications for the increasing threat of drought to maize in Indonesia [5], people no need to be feared, because Indonesia has a rich diversity of maize germplasm [6], which can be exploited its potential to assemble superior varieties of maize. In addition,

*Corresponding author: tydars66@gmail.com 
the condition of the area where rice plants are less successful in conditions of water shortage, can be diverted its use for corn crops, because farmers in Indonesia usually plant maize as intercrop [7].

During the last two decades, there have been quite a number of superior varieties of maize produced in Indonesia, among which farmers are much sought after: Abhimanyu, Arjuna, Bromo, Bastar Kuning, Bima, Quickly Kertas, Harapan, Harapan Baru, Hybrid C 1 (Cargil Hybrid 1), IPB 4 hybrids, Kalingga, Kania Putih, Malin, Metro, Nakula, Pandu, Parikesit, Permadi, Sadewa, Wiyasa, Bogor Composite [8]. Unfortunately, even so, productivity problems are still a major obstacle in achieving self-sufficiency in maize [9]. Domestic maize supply is only available during certain seasons, in addition to competition between users for food in the form of young corn, corn rice and various food industries made from corn [2].

National maize production is basically supported by two main components, i.e.: the composite maize and the hybrid maize [8]. Composite maize is usually the result of breeding derived from free-fringed maize, while hybrid maize is the result of assembly by combining several inbred maize which have targeted characteristics.

Regarding cultivation, maize is classified as not a complicated plant, in the sense that by cultivating only with standards, superior maize will still produce optimally. However, it is different if the problem is a genetic barrier. Even though it is managed with a very special cultivation, if the genetics is a bad breed, it does not guarantee that the results will be optimal. Therefore, genetic improvement and assembly of new varieties need to be carried out in order to assemble high-yielding varieties, in such a way that the target of selfsufficiency in maize can be achieved.

This study aims to characterize 50 inbred maize, especially the quantitative characters that have a high contribution to yield components, as well as some of the main qualitative characters to determine the level of uniformity / similarity of the tested inbred lines.

\section{Material and Method}

\subsection{Material and method}

The research was conducted at the Cikeumeuh Experimental Garden at Indonesian Center for Agricultural Biotechnolgy and Genetic Research And Development (ICABIOGRAD), Bogor from June to October 2015.

A total of 50 accessions of ICABIOGRAD inbred maize germplasm collection (Table 1) were tested in a randomized block design with three replications with the population of 75 plants for each accession. Inbred maize was planted at a spacing of $75 \mathrm{~cm}$ x $20 \mathrm{~cm}$ and each genotype was planted in 3 rows $5 \mathrm{~m}$ long. Basic fertilization is carried out when the plants are 10 days after planting with a fertilizer rate of $75 \mathrm{~kg} \mathrm{~N}$ ha-1, P $60 \mathrm{~kg}$ ha- 1 and $\mathrm{KCl} 60 \mathrm{~kg}$ ha-1. The second fertilization is carried out after the plants are 30 days after planting at a dose of $75 \mathrm{~kg} \mathrm{~N}$ ha-1.

Plant maintenance including fertilization, weed control and pest control in the planting area is carried out according to plant cultivation standards. Observations on the characters that included yield components included: ear length, ear diameter, number of rows per ear, number of seeds per ear, ear wet weight, ear dry weight, dry seed weight, bulk moisture content, and bulk weight of 1000 seeds.

The qualitative characters observed include: stem color (SC), sheath pubescence (SP), tassel type (T), anthocyanin color in sheath (An), Leaf apex (LA), Leaf color (LC), Undulation of margin of blade (Un), Leaf angel (Lan). The determination of the scoring of this qualitative character refers to the Descriptor for maize [10]. 


\subsection{Data analysis}

Descriptive statistics, Anova, Pearson correlation regression analysis, and clustering using Average-linkage with Euclidean Distance were used to analyze the phenotypic data. Differences among the measured variables were considered as significantly different when the $\mathrm{p}$-value was $<0.001$. The clustering using Average-linkage with Euclidean Distance was also applied based on the level of similarity at 50\%. All calculation and operation were conducted using the Minitab 19.

Table 1. List of 50 accessions of inbred maize lines in this study

\begin{tabular}{|c|c|c|c|}
\hline No. & Name of Inbred lines & Province of collection & No. accession \\
\hline 1 & ARC 83-2-3-1-1-1-2-1-XB3 & West Java & 3790 \\
\hline 2 & ARC 103-3-5-1-2-XB3 & West Java & 3792 \\
\hline 3 & ARC 178-1-4-3-2-2-XB3 & West Java & 3793 \\
\hline 4 & ARC 178-1-4-1-3-2-1-1-XB3 & West Java & 3794 \\
\hline 5 & ARC 178-1-3-1-1-4-1-1-XB3 & West Java & 3795 \\
\hline 6 & ARC 178-1-3-1-1-4-2-2-XB3 & West Java & 3796 \\
\hline 7 & ARC 178-1-4-1-1-1-5-1-XB3 & West Java & 3797 \\
\hline 8 & ARC 178-1-4-1-1-3-2-2-XB3 & West Java & 3798 \\
\hline 9 & ARC 178-1-4-1-1-4-2-1-XB3 & West Java & 3799 \\
\hline 10 & ARC 83-2-7-2-3-1-1-1-2 & West Java & 3875 \\
\hline 11 & ARC 178-1-2-1-1-4-1-1 & West Java & 3871 \\
\hline 12 & ARC 83-2-3-1-1-2-2-1 & West Java & 3846 \\
\hline 13 & ARC 83-2-3-1-1-1-2-1 & West Java & 3845 \\
\hline 14 & ARC 178-1-4-1-3-1-2-1 & West Java & 3841 \\
\hline 15 & ARC 178-1-4-1-3-1-2-3 & West Java & 3838 \\
\hline 16 & ARC 178-1-4-1-3-1-2-2 & West Java & 3836 \\
\hline 17 & ARC 178-1-4-1-3-1-2-1 & West Java & 3835 \\
\hline 18 & ARC 178-1-3-1-1-1-4-1-1 & West Java & 3821 \\
\hline 19 & ARC 178-1-3-1-1-4-1-2-OB & West Java & 3822 \\
\hline 20 & ARC 178-1-3-1-1-4-1-2-OB & West Java & 3823 \\
\hline 21 & ARC 178-1-3-1-1-1-4-2-2-OB & West Java & 3826 \\
\hline 22 & ARC 178-1-4-1-1-4-2-2 & West Java & 3831 \\
\hline 23 & ARC 178-1-4-1-1-4-4-4 & West Java & 3832 \\
\hline 24 & ARC 178-1-4-1-1-5-3-1 & West Java & 3833 \\
\hline 25 & ARC 178-1-4-4-1-1-5-3-1 & West Java & 3834 \\
\hline 26 & ARC 94-4-3-3-1-2-1-2 & West Java & 3884 \\
\hline 27 & P5G18 (S) C3-K14-9-1-1 & West Java & 3986 \\
\hline 28 & P5G18 (S) C3-K14-4-3-1 & West Java & 3983 \\
\hline 29 & P5G18 (S) C3-K14-1-1 & West Java & 3985 \\
\hline 30 & P5G18 (S) C3-K14-1-3-1 & West Java & 3981 \\
\hline 31 & P5G18 (S) C3-K14-129-1 & West Java & 3980 \\
\hline 32 & ARC 178-1-4-1-2-5-2-1-XB3 & West Java & 3879 \\
\hline 33 & P5G18 (S) C3-K14-114-1-1 & West Java & 3977 \\
\hline 34 & P5G18 (S) C3-K14-24-1-1 & West Java & 3976 \\
\hline 35 & P5G18 (S) C3-2-14-20-7-1 & West Java & 3973 \\
\hline 36 & P5G18 (S) C3-1-14-208-2-1 & West Java & 3972 \\
\hline 37 & P5G8 (S) C3-25-1-1-1 & West Java & 3966 \\
\hline 38 & P5G8 (S) C3-200-21-1-1-1 & West Java & 3965 \\
\hline 39 & P5G18 (S) C2-80-2-1-2 & West Java & 3964 \\
\hline
\end{tabular}




\begin{tabular}{|c|l|c|c|}
\hline No. & Name of Inbred lines & Province of collection & No. accession \\
\hline 40 & P4G19 (S) C2-114-3-1 & West Java & 3960 \\
\hline 41 & P4G19 (S) C2-126-1-1 & West Java & 3959 \\
\hline 42 & P4G19 (S) C2-64-1-2 & West Java & 3958 \\
\hline 43 & P4G19 (S) C2-64-1-1 & West Java & 3957 \\
\hline 44 & P4G18 (S) C2-18-1-1 & West Java & 3955 \\
\hline 45 & P4G19 (S) C2-15-1-1 & West Java & 3954 \\
\hline 46 & P4G19 (S) C2-114-3-1-1 & West Java & 3928 \\
\hline 47 & P4G19 (S) C2-114-3-1-2 & West Java & 3929 \\
\hline 48 & P4G19 (S) C2-15-1-1-4 & West Java & 3930 \\
\hline 49 & P4G19 (S) C2-59-3-3-13 & West Java & 3931 \\
\hline 50 & P4G19 (S) C2-90-1-2-1 &
\end{tabular}

\section{Result and Discussion}

Maize has enormous genetic diversity which offers tremendous opportunities for genetic enhancement regardless of environmental challenges [11]. There is no shortage of favorable alleles in global maize germplasm contributing to higher yields, abiotic stress tolerance, disease resistance or improved nutritional quality. Description of maize inbred lines based on quantitative traits is the first way to identify them.

One way to increase maize production is to assemble high yielding superior maize varieties. The initial stage is to select inbred maize, especially the yield component characters for the formation of superior maize varieties [12]. Related to this, the characters that contribute to the results need to be known when selecting the inbreds that will be used as parents.

In this study, quantitative and qualitative characterizations of 50 inbreds were carried out which included the following characters: ear length, ear diameter, number of rows per ear, number of seeds per ear, ear wet weight, ear dry weight, dry seed weight, bulk moisture content, and bulk weight of 1000 seeds. In addition, qualitative characterization has also been carried out, including: stem color (SC), sheath pubescence (SP), tassel type (T), anthocyanin color in sheath (An), Leaf apex (LA), Leaf color (LC). Undulation of margin of blade (Un), Leaf angel (Lan).

\subsection{Analysis of Quantitative and Qualitative characters}

\subsubsection{Quantitative characters}

Table 2. Descriptive analysis result

\begin{tabular}{|l|r|r|r|r|r|r|r|}
\hline Variable & Mean & $\begin{array}{l}\text { SE } \\
\text { Mean }\end{array}$ & StDev & Variance & CoefVar & \multicolumn{1}{l|}{ Min } & \multicolumn{1}{l|}{ Max } \\
\hline Ears length & 11.73 & 0.31 & 2.16 & 4.66 & 18.41 & 7.20 & 15.75 \\
\hline Ears diameter & 3.31 & 0.04 & 0.31 & 0.09 & 9.43 & 2.67 & 3.91 \\
\hline Number of line per ear & 11.11 & 0.13 & 0.93 & 0.87 & 8.38 & 9.20 & 13.20 \\
\hline Number of seed per ear & 201.12 & 8.98 & 63.50 & $4,032.29$ & 31.57 & 52.33 & 325.60 \\
\hline Ears wet weight & 64.81 & 2.65 & 18.74 & 351.03 & 28.91 & 21.67 & 100.50 \\
\hline Ears dry weight & 49.73 & 2.60 & 18.37 & 337.64 & 36.95 & 12.50 & 88.50 \\
\hline Seeds dry weight & 39.09 & 2.24 & 15.86 & 251.5 & 40.57 & 7.50 & 70.00 \\
\hline Moisture (bulk) & 11.88 & 0.11 & 0.79 & 0.638 & 6.73 & 10.8 & 14.90 \\
\hline 1000 seeds weight (bulk) & 189.04 & 4.91 & 34.75 & $1,207.84$ & 18.38 & 120 & 255.00 \\
\hline
\end{tabular}


Descriptive analysis was carried out on 50 inbred maize lines characters, including: ear length, ear diameter, number of ear rows-1, number of cobs-1 seeds, ear wet weight, ear dry weight, dry seed weight, moisture content and 1000 bulk seed weight (Table 2). The character with the highest coefficient of variance was dry seed weight, while the one with the lowest variance was ear diameter.

\section{a. Ears Length}

Based on the observation on the length of the cob, the average length of the inbred cob in this study was $11,727 \mathrm{~cm}$. The inbred with the longest ear length was P4G19(S)C2-593-3-13 with an average length of $15.75 \mathrm{~cm}$. In addition, there are also P4G19(S)C2-64-1-2 and ARC178-1-4-1-1-4-4-4 which have an average cob length of $15.10 \mathrm{~cm}$. The inbreds with the shortest cobs were ARC 178-1-4-1-1-1-5-1-XB3 with an average length of 7.20 $\mathrm{cm}$. In addition, there are other short inbreds, namely P5G8(S)C3-200-21-1-1-1 with an average length of $7.85 \mathrm{~cm}$.

\section{b. Ears Diameter}

Observations on the diameter of the cobs noted that the average diameter was $3.3122 \mathrm{~cm}$. The inbred with the largest ear diameter was obtained from P4G19(S)C2-15-14 with a diameter of $3.91 \mathrm{~cm}$. The inbred with the shortest ear diameter was obtained from P5G18(S)C3-K14-24-1-1 with a length of $2.67 \mathrm{~cm}$.

\section{c. Number of rows per ears}

Observations on the number of rows per ear recorded an average value of 11,105 rows per ear, where inbred P4G19(S) C2-15-1-14 had the highest number of rows per ear (13.20), and inbred ARC 83-2-7-2-3. -1-1-1-2 has the lowest number of rows.

\section{d. Number of seeds per ears}

Based on observations, the average number of seeds per ear of 50 inbreds observed was 201.12, where inbred P4G19(S) C2-15-1-1-4 had the highest number of seeds per ear, which was 325.60; while the ARC 178-1-4-1-1-5-1-XB3 inbred had the lowest number of seeds per ear, which was 98.40 .

\section{e. Wet Ears Weight}

Observation of 50 inbred corn in this study obtained an average wet weight of the cobs of 64.81. Inbred which has the highest wet weight of cobs is P4G18 (S) C2-18-1-1 with a wet weight of up to 100.5 grams. The inbreds with the lowest cob wet weight were P5G18 (S) C3-K14-114-1-1, with weight 21.67 gram.

\section{f. Dry Ears Weight}

Based on observations of 50 inbred corn in this study, the average cob weight was 49.73 grams. The inbreds with the highest dry weight of cobs were P4G18 (S) C2-18-1-1 with a weight of 88.50 grams; while the inbred with the lowest dry weight of cob was P5G18 (S) C3-K14-114-1-1 with a weight of 12.50 grams.

\section{g. Dry Seed Weight}

The results of observations on the dry seed weight of 50 inbreds in this study obtained an average value of 39.09 grams. The inbred with the highest dry seed weight was P4G19 (S) C2-114-3-1-2 with a dry seed weight of 70 grams, while the inbred with the lowest dry seed weight was P5G18 (S) C3-K14-114-1-1 with seed weight 7.50 grams.

h. Weight 1000 bulk 
Based on observations on the weight of 1000 seeds, the average yield was 189.4 grams. The inbred with the largest 1000 bulk weight was ARC 83-2-3-1-1-1-2-1 with a weight of 255 grams, while the inbred with the lowest 1000 bulk weight was ARC 83-2-3-1-1-1- 2-1XB3 weighing 120 grams. Based on ANOVA analysis, the effect of genotype and replication on the seven observed characters (ears length, ears diameter, number of line per ears, number of seed per ears, ears wet weight, ears dry weight and dry seed weight) was significant (Table 3).

Table 3. F-value dan $P$ value for Ear Length, ear diameter and number of lines.ears ${ }^{1}$

\begin{tabular}{|c|c|c|c|c|c|c|}
\hline \multirow{2}{*}{ Source } & \multicolumn{2}{|c|}{$\sum$ Seed per ears } & \multicolumn{2}{|c|}{ Ears wet weight } & \multicolumn{2}{|c|}{ Ears dry weight } \\
\hline & F-value & P-value & F-value & P-value & F-value & P-value \\
\hline Genotype & 17.52 & 0 & 28.1 & 0 & 38.17 & 0 \\
\hline Rep & 29.04 & 0 & 90.29 & 0 & 103.74 & 0 \\
\hline \multirow{2}{*}{ Source } & \multicolumn{2}{|c|}{ Ears Lenght } & \multicolumn{2}{|c|}{$\varnothing$ Ears diameter } & \multicolumn{2}{|c|}{$\sum$ Line per ears } \\
\hline & F-value & P-value & F-value & P-value & F-value & P-value \\
\hline Genotype & 5.37 & 0 & 16.27 & 0 & 4.86 & 0 \\
\hline Rep & 9.12 & 0 & 35.07 & 0 & 6.71 & 0 \\
\hline \multirow{2}{*}{ Source } & \multicolumn{6}{|c|}{ Dry seed weight } \\
\hline & F-value & \multicolumn{5}{|l|}{ P-value } \\
\hline Genotype & 45.36 & \multicolumn{5}{|l|}{0} \\
\hline Rep & 119.23 & \multicolumn{5}{|l|}{0} \\
\hline
\end{tabular}

\subsubsection{Qualitative characters}

Descriptive analysis of qualitative characters showed that leaf apex, sheath pubescence, anthocyanin color and stem color had higher diversity than leaf angle, tassel type, leaf color and undulation of margin blade (Table 4).

Table 4. Descriptive statistic of qualitative characters of 50 inbreds of maize

\begin{tabular}{|l|r|c|c|r|r|c|c|}
\hline Variable & Mean & SE Mean & St Dev & Variance & Coef Var & Min & Max \\
\hline Stem colour & 2.38 & 0.0943 & 0.6667 & 0.4445 & 28.01 & 1 & 3 \\
\hline Sheath pubescence & 2.22 & 0.104 & \multicolumn{1}{|c|}{0.737} & 0.542 & 33.18 & 1 & 4 \\
\hline Tassel type & 1.72 & 0.0702 & 0.4965 & 0.2465 & 28.87 & 1 & 3 \\
\hline Anthocyanin colour in sheath & 2.48 & 0.0958 & 0.6773 & 0.4588 & 27.31 & 1 & 4 \\
\hline Leaf apex & 2.2 & 0.146 & 1.03 & 1.061 & 46.83 & 1 & 4 \\
\hline Leaf colour & 1.68 & 0.083 & 0.5869 & 0.3445 & 34.94 & 1 & 3 \\
\hline $\begin{array}{l}\text { Undulation of margin of } \\
\text { blade }\end{array}$ & 2.18 & 0.0842 & 0.5956 & 0.3547 & 27.32 & 1 & 4 \\
\hline Leaf angle & 1.84 & 0.0661 & 0.4677 & 0.2188 & 25.42 & 1 & 3 \\
\hline
\end{tabular}

Based on correlation analysis (Table 5), all observed characters had a positive correlation, and almost all of them had a significant correlation, except for the genotype on the number of rows per ear and weight of 1000 seeds, and the weight of 1000 seeds on the number of rows per ear. The highest correlation value is found in the relationship between DSW (dry seed weight) and DEW (dry ears weight) which is 0.985 . Meanwhile, the lowest correlation was found in the number of rows per ear on the genotype.

The length of the ear, the diameter of the ear, the number of rows per ear and the number of seeds per ear are characters that are closely related to yield. The length of the cob according to Pabendon [13] had a significant correlation with the weight of 1000 seeds, 
the diameter of the cob, and dry shells. This is in accordance with the results of the correlation analysis in this study where the length of the cob has a significant correlation with the weight of 1000 seeds and the diameter of the cob.

Table 5. Correlation analisys between quantitative characters

\begin{tabular}{|l|r|r|r|r|r|r|r|r|c|}
\hline & \multicolumn{1}{|c|}{ G } & \multicolumn{1}{c|}{ EL } & ED & NEL & NSE & WSW & DEW & DSW & M \\
\hline EL & 0.354 & & & & & & & & \\
\hline ED & 0.361 & 0.705 & & & & & & & \\
\hline NEL & 0.14 & 0.382 & 0.534 & & & & & & \\
\hline NSE & 0.394 & 0.717 & 0.758 & 0.617 & & & & & \\
\hline WSW & 0.453 & 0.66 & 0.774 & 0.524 & 0.904 & & & & \\
\hline DEW & 0.457 & 0.79 & 0.857 & 0.506 & 0.923 & 0.944 & & & \\
\hline DSW & 0.436 & 0.75 & 0.835 & 0.514 & 0.927 & 0.937 & 0.985 & & \\
\hline M & 0.443 & 0.585 & 0.567 & 0.406 & 0.677 & 0.654 & 0.663 & 0.658 & \\
\hline 1000GW & 0.32 & 0.497 & 0.646 & 0.077 & 0.409 & 0.611 & 0.673 & 0.696 & 0.301 \\
\hline
\end{tabular}

Note: $\mathrm{G}=$ genotype; $\mathrm{EL}=$ ears length; $\mathrm{ED}=$ ears diameter; $\mathrm{NEL}=$ number of ears line; $\mathrm{NSE}=$

Number of seed per ears; WSW=wet seed weight; DEW=dry ears weight; DSW=dry

Seed weight; $\mathrm{M}=$ mouisture; $1000 \mathrm{GW}=1000$ grain weight

\subsection{Heritability of the traits}

The length of the ear, the diameter of the ear, the number of rows per ear and the number of seeds per ear are the characters that are closely related to yield. Knowing the heritability of these characters is important, because individuals who have characters with high heritability can later be used as parental in breeding.

Table 6. Heritability of several quantitative traits in this study

\begin{tabular}{|c|c|c|}
\hline Variable & \multicolumn{2}{|c|}{ Heritability } \\
\hline Ears length & 30.417 & Moderate \\
\hline Ears diameter & 60.421 & High \\
\hline$\sum$ ears line & 27.823 & Moderate \\
\hline$\sum$ ears seed & 62.289 & High \\
\hline Ears wet weight & 73.042 & High \\
\hline Ears dry weight & 78.709 & High \\
\hline Seed dry weight & 81.605 & Very High \\
\hline
\end{tabular}

The character with the highest heritability was seed dry weight $(\mathrm{h}=81.605)$ while the one that was classified as moderate (in this case, the lowest heritability) was the $\sum$ ears line $(h=27.823)$. Other characters which showed high heritability were ears dry weight, ears wet weight, number of ears seed, and ears diameter (Table 6).

\subsection{Clustering for Qualitative and Quantitative Characters}

Clustering based on qualitative characters (SC, SP, T, An, LA, LC, Un and Lan) Standardized Variables, Euclidean Distance, Average Linkage- 50\% similarity classifies 50 maize inbreds into 6 groups (Figure 1), where group one has most members (42 inbred lines) which indirectly indicated that the phenotypic-qualitative inbreds tested were close to homogeneous on a scale of up to 50 percent especially for the characters SC, SP, T, An, LA, LC, Un and Lan. The other 5 groups (or a total of 8 inbred accessions) still showed high variation for these characters. 


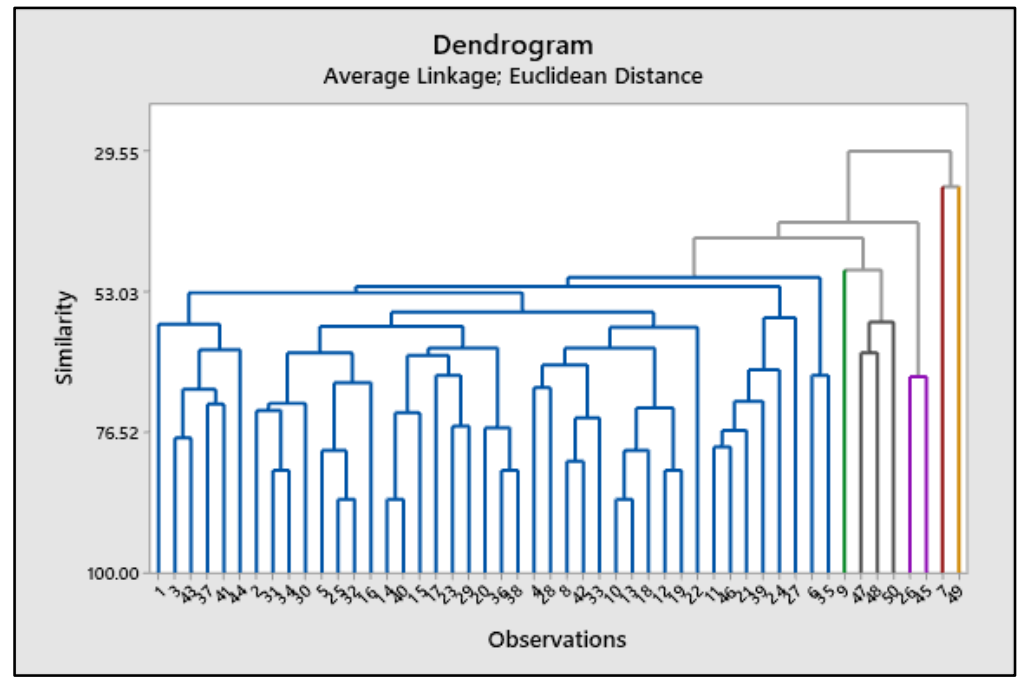

Fig. 1. Clustering based on qualitative traits with the Average-Linkage method

Clustering based on the quantitative characters of the bulk weight of 1000 seeds, genotype and number of rows of cobs using the Average Linkage-Euclidean Distance method with a similarity level of $75 \%$ turned out to be placing 50 maize inbreds into 4 groups (Figure 2), distance measures quantify the dissimilarity between the clusters, where these results showed difference when compared to clustering based on qualitative characters which grouped the evaluated inbreds into 6 groups (Fig 1).

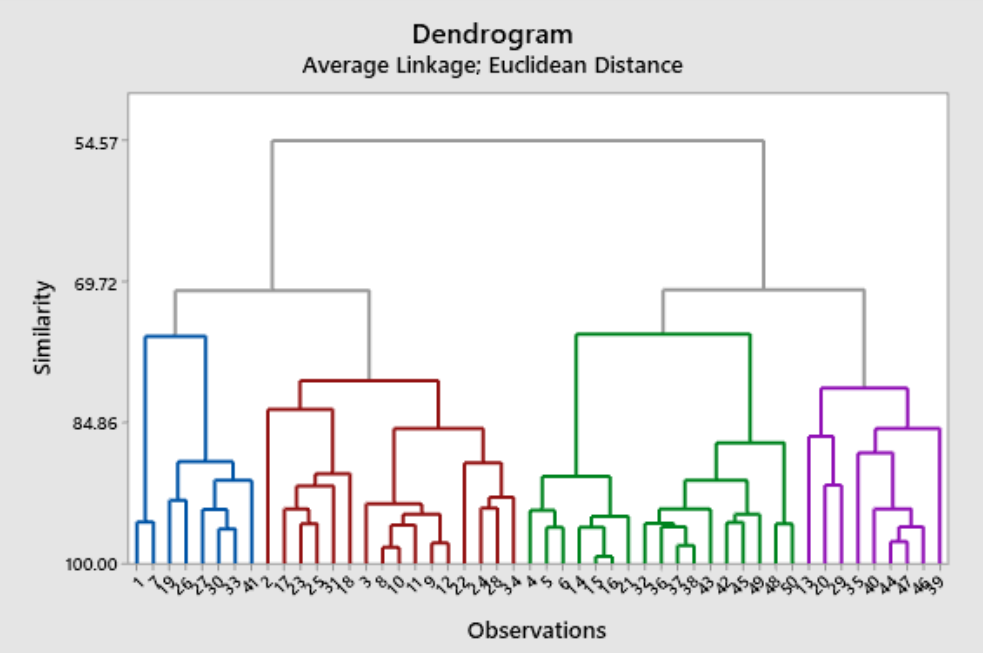

Fig. 2. Clustering based on quantitative traits with the Average-Linkage method

Clustering based on qualitative characters can be seen from Figure 1. Although this method grouping the maize inbreds into 6 different groups, there is a group that has the largest members which reaching 42 members. While the other groups only consisted one to three members. This is interesting, because based on this information, it can be suggested that the homogeneity of the tested inbred lines is quite high - in terms of its qualitative character.

However, different results were obtained for grouping based on quantitative characters, where even though we only separated the inbred lines into 4 different groups, the groups 
had almost the same number of members (Figure 2). Thus, the high variation in quantitative characters observed in the tested maize inbreds indicates the homogeneity of the inbreds is still low (or the heterogeneity between inbreds is still relatively high). In other words, fixation of the same genes has not been fully achieved. This is really interesting because the inbred tested are derived from the selfing generation of the 5th and 8th parent. Usually inbred lines should have reached homogeneity (having high homogeneity) after reached 5 th generation of selfing or more.

In addition, the difficulty of achieving high homogeneity may also be caused by the character of the maize plant. Corn is a naturally cross-pollinated species, meaning it has a heterogeneous genetic composition. The degree of heterozygosity on the quantitative characters may be higher than the qualitative characters. The reason is, quantitative characters are generally controlled by many genes, while qualitative characters are, on the other hand, controlled by major genes (only few genes). Thus, selfing required to fix a character controlled by many genes certainly requires more frequency than fixation of a character controlled by only a few genes. In other words, achieving homogeneity for quantitative characters requires a higher selfing frequency than selfing frequency for qualitative character fixation.

Thus, based on this study, we suggested that the qualitative character of the tested inbred homogeneity has reached its maximum, but quantitatively has not. However, some inbreds that have the most prominent characteristics (ears length, number of lines per ear, seed weight, etc.) can be used as crossbreeding materials in the formation of hybrid maizes.

\section{Conclusion}

This research has succeeded in obtaining several inbred maize, with the following potential characteristics: . The accession with the highest dry seed weight was P4G19(S)C2-114-3-1-2 (70 g), accession with the largest ear diameter and the highest number of seeds per ear was P4G19(S)C2-15$1-1-4$, and the one with the largest ear dry weight was P4G18(S)C2-18-1-1. These inbreds have the potential to be used as parents in hybrid formation materials. The tested inbreds have achieved a high level of homozygosity for their qualitative characters, but not yet achieved their quantitative characters.

\section{Reference}

1. UNICEF, UNDP, Prospera, SMERU. Analysis of the Social and Economic Impacts of COVID-19 on Households and Strategic Policy Recommendations for Indonesia, Jakarta (UNICEF, 2021)

2. N. Herlina, A. Prasetyorini. JIPI 25, 1: 118-128 (2020)

3. Sutoro. IPTEK Tanaman Pangan 7, 2: 108-115 (2012)

4. D. Shim, K.J. Lee, B.W. Lee. The Crop Journals 4, 5: 305 - 316 (2017)

5. R. Effendi, S.B. Priyanto, M. Aqil, M. Azrai. IOP Conf. Ser: Earth Environ. Sci, 270 (2019)

6. M. Yasin, Sumarno, A. Nur. Perakitan Varietas Unggul Jagung Fungsional (IAARD-Press, Jakarta 2014)

7. Y. Yuwariah, N.P. Indriani, M. Ariyanti, E. Azizah, D. Ruswandi. J. Agron. 19, 1: 31-39 (2020)

8. Zubachtirodin, F. Kasim. 2012. Buletin Iptek Tanaman Pangan 7, 1: 25-31 (2012)

9. N. Yang, J.B. Yan. Current Opinion in Plant Biology, 60:101977- 101986 (2021) 
10. CYMMIT. Description for Maize (CYMMIT, 1991)

11. L.N. Tandzi, E.M. Ngonkeu, E. Nartey, M. Yeboah, H.A. Mafouasson, K. Moche, H. Tekeu, J. Ngeve, V. Gracen. International Journal of Current Research 7, 5:1553815544 (2015)

12. J. Chen, W. Xu, J. Velten, Z. Xin, J. Stout. J. Soil Water Conserv. 67, 5:354-364 (2012)

13. M.B. Pabendon. Analisis korelasi pola heterotik inbrida berbasis marka mikrosatelit dalam menduga penampilan fenotipik hasil silang uji dan silang dialel hibrida jagung [thesis] (2006) 